\title{
Lolium Multiflorum SEEDS IN THE SOIL: II. LONGEVITY UNDER NATURAL CONDITIONS ${ }^{1}$
}

\author{
FERNANDA COSTA MAIA², MANOEL DE SOUZA MAIA³, RENÉE M. BEKKER ${ }^{4}$, \\ ROGÉRIO PREVIATTI BERTON ${ }^{5}$, LEANDRO SEBASTIÃO CAETANO ${ }^{5}$
}

\begin{abstract}
The interest was the seed longevity dynamics of annual ryegrass in natural conditions as an important tool to explain its dynamics in no tillage systems used in the South of Brazil. The species is commonly managed for natural re-sowing and, in this way, allows cattle grazing with reduced costs during the winter time. In February of 2003, twenty bags of nylon screen containing sterilised soil with 100 seeds in each were randomly buried in the field, $5 \mathrm{~cm}$ deep. Around every three or four months, four sacks were exhumed. Seeds were counted and tested using germination and tetrazolium tests. The seeds showed high primary dormancy, which was overcome very fast. After 108, 226, 326, 565 and 732 days of burial there were no significant differences as the secondary dormancy of the seeds that did not germinate in autumn was not high. The last exhumation period was significantly different from the others due to the strong decay on seed viability. As few seeds remained viable after 732 days, the soil seed bank was classified as transient, being evident that in annual pastures the transitory seed banks have a main role in the regeneration of the species.
\end{abstract}

Index terms: annual ryegrass, persistence, viability, dormancy, buried seeds.

\section{SEMENTES DE Lolium multiflorum NO SOLO: II. LONGEVIDADE SOB CONDIÇÕES NATURAIS}

\begin{abstract}
RESUMO - O objetivo do presente trabalho foi determinar a dinâmica de longevidade da semente de azevém anual em condições naturais como uma importante ferramenta no sistema de plantio direto usado no Sul do Brasil. A espécie é comumente manejada para ressemeadura natural, que neste caso, permite utilização sob pastejo durante o inverno, com custo reduzido. Em fevereiro de 2003, vinte sacos de tecido de nylon contendo solo esterilizado contendo 100 sementes cada um, foram enterrados no campo, ao acaso, numa profundidade de $5 \mathrm{~cm}$. A cada três ou quatro meses, quatro sacos foram exumados. As sementes foram contadas e avaliadas fisiológicamente através dos testes de germinação e tetrazólio. As sementes apresentaram elevada porcentagem de dormência primária, a qual foi superada rápidamente. Após 108, 226, 326, 565 e 732 dias de enterrio não houve diferenças significativas devido a dormência secundária, não apresentando germinação alta no outono. $\mathrm{O}$ último
\end{abstract}

\footnotetext{
${ }^{1}$ Submetido em 01/09/2006. Aceito para publicação em 04/04/2007. Part of the Thesis of the first author, presented to Post-Graduation Program of Seed Science and Technology, Federal University of Pelotas, Pelotas-RS, Brazil. Financial support by CNPq.

${ }^{2}$ Agr. Eng., Researcher, Dr. State Foundation of Agricultural Research BR 392, km 36, Domingos Petrolini, Rio Grande-RS, Brazil (E-mail:fecmaia@ terra.com.br).
}

${ }^{3}$ Professor, Dr. Federal University of Pelotas, Department of Plant Science, P.O.Box 354, Pelotas-RS, Brazil

${ }^{4}$ Biol., Researcher, Dr. University of Groningen, Community and Conservation Ecology Group, Groningen, The Netherlands

${ }^{5}$ Students, Agronomy Course, Federal University of Pelotas, Pelotas-RS, Brazil. 
período de exumação foi significativamente diferente dos demais, devido a alta porcentagem de apodrecimento e perda de viabilidade das sementes. Como poucas sementes permaneceram viáveis após 732 dias de enterrio, o banco de sementes do solo foi classificado como transitório, sendo evidente que nas pastagens de azevém anual tem a principal função de regeneração da espécie.

Palavras chave: azevem annual, persistência, viabilidade, dormência, banco de sementes.

\section{INTRODUCTION}

For perennial plants, seeds are an alternative to perpetuate the species, but they are not as important as they are for the annuals, where the dormant seed is the crucial link between generations (Harper, 1977). Seeds of perennial species normally do not stay viable in the soil for a long time, as the annuals (Pettit and Froend, 2001) that can have extremely long life cycles (Cook, 1980). The number of viable seeds in the soil normally decreases with the reduction of the disturbance frequency and the increase of vegetation longevity (Symonides, 1986).

A lot of species that accumulate a big number of seeds in the soil have dormant seeds or, at least, populations partially dormant. The fact that these species have a great number of long-lived seeds, along with the dormancy polymorphism or the development of secondary dormancy, allows germination flows for a long period of time. As these plants produce a great number of small seeds, a lot of them probably penetrate in the soil and get vertically distributed in the first layers (Bryant, 1989).

Seed bank composition depends on the production and composition of the previous and current vegetable communities, as well as the seed longevity of each species under local conditions (López-Mariño et al., 2000). Stocklin and Fischer (1999) demonstrated that seed longevity is highly correlated with the index of extinction of some grassland species. Seed longevity is, therefore, an important topic for management practices for recovery of degraded areas (Bekker et al., 1998a; Bekker et al., 1998b; Bakker and Berendse, 1999), revealing the possible vulnerability of the vegetation to the extinction, including its soil seed banks, the need of its conservation and possibilities of regeneration (Bekker et al., 1998c). This relationship between the composition of the soil seed bank and the vegetation is very important in areas with different management practices (Fredrickson and Taylor, 1982 apud López-Mariño, 2000).

In the case of Lolium multiflorum in the South of Brazil, the interest was in its longevity in natural conditions as an important information to the knowledge of its dynamics in no tillage systems. The species is managed for natural resowing and, in this way, allows cattle grazing with reduced costs during the winter time. The soil seed bank dynamics of the pasture was classified as transient or short-term persistent (Maia et al., 2008). However, there is the need for more information on the effects of the environmental conditions on the longevity and survival of seeds in natural conditions, which will make possible to determine how long these seeds that do not germinate in the next growing period can survive in the soil.

This study aimed to determine the loss of viability of $L$. multiflorum seeds in natural conditions.

\section{MATERIALS AND METHODS}

The study was carried out in the South of Brazil, in the Southeast of Rio Grande do Sul state (Pelotas), 31 38' 00"S and $52^{\circ} 27^{\prime} 00^{\prime \prime} \mathrm{W}$, from February/2003 to September/2004.

Region climate is considered to be subtropical in general, with four well defined seasons of the year, well distributed rains throughout the year (1300 to $1500 \mathrm{~mm}$ ), annual medium temperature of $17{ }^{\circ} \mathrm{C}$ and possible frost in the period from April to September (15 to 20 times). The area has a wavy soft relief and loamy texture soils, not well drained, with good chemical and physical characteristics, deep and with excessive superficial compacted soil. The soil shows a strong variation in the phosphorus and potassium indexes according to the depth. The $\mathrm{pH}$ varies from 4.4 to 5.1 .

In February of 2003, sterilized bags of nylon screen containing soil with 100 seeds with $80 \%$ of germination rate in each were randomly buried, around $5 \mathrm{~cm}$ of depth.

Around every three months, four bags were exhumed. Seeds were counted and tested, at a constant temperature of $20{ }^{\circ} \mathrm{C}$, by germination test according to the Rules of Seed Analysis (Brasil, 1992). Seeds that did not germinate in 14 days were submitted to tetrazolium test in order to verify 
their viability.

Multivariate analyses were carried out with the software MULTIV 2.3.4. (Pillar, 1997; Pillar, 1994-2004). Euclidean distance was the resemblance measure used and a randomization test was make to identify significant differences between the periods of burial ( $5 \%$ of probability).

\section{RESULTS AND DISCUSSION}

Figure 1 shows the initial situation of the seeds and what happened after each exhumation, with the significant differences between these periods, considering all analysed variables, there were significant differences between the initial conditions and the exhumation periods, but not among the three first exhumations, except among 226 and the two last ones, 565 and 732 days of burial.

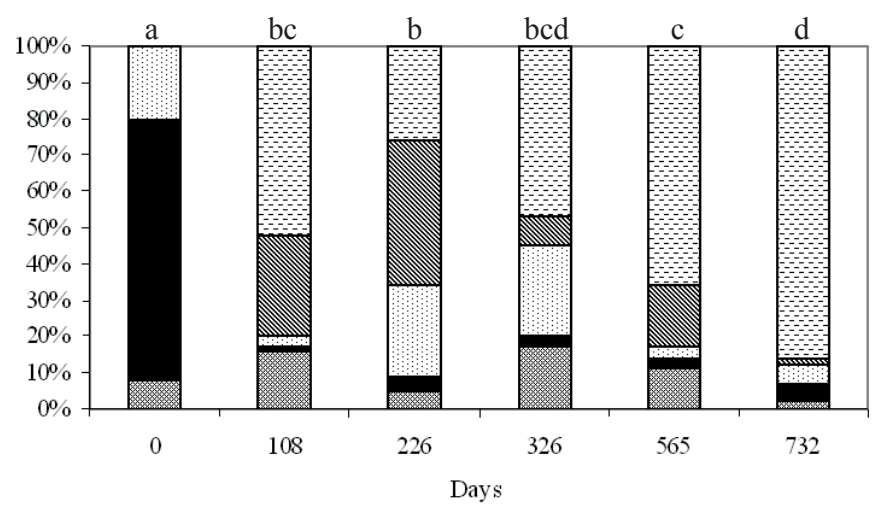

圆 Viable $\square$ Dormant $\square$ Non viable $\mathbb{Q}$ Field germinated $\square$ Non identified lost

\section{FIGURE 1. Changes observed in the seeds of the burial experiment and significant differences $(P<0.05)$ between the exhumation periods of them, considering the whole set of variables that were analyzed.}

The seeds in February showed a high dormancy index (72\%). Just $8 \%$ of the seeds germinated. According to the tetrazolium test, around $80 \%$ of the buried seeds were viable.

After 108 days of burial, $52 \%$ of the seeds were not detected anymore probably due to germination, but also predation or decay, as $28 \%$ of seedlings were detected in the samples. Just $16 \%$ of the seeds were still viable. A low rate of dormancy was detected (around 3 and 4\%) in all exhumations periods (Figure 1).

After 326 days of burial, the field germination index decreased considerably and the number of non viable seeds increased. The number of viable seeds was almost the same.

After 565 days, the number of viable seeds decreased more $(11 \%)$ and the number of non viable seeds showed a strong decrease, as the identification of injured seeds from the samples was not possible anymore, and most of these seeds were then classified as non-identified lost.

After 732 days of burial, just $12 \%$ of the initial number of seeds was found, and $2 \%$ were viable. The percentage of dormant seeds was practically stable $(5 \%)$.

Figure 1 shows the initial situation of the seeds and what happened after each exhumation, with the significant differences between these periods, considering all analysed variables

Seeds in the soil may be in a variety of physiological states. Although non-dormant seeds have a slight tendency to be less persistent, almost all combinations of persistence and dormancy exist (Thompson et al., 2003).

Overcoming of dormancy should not be confused with germination, as they are different process that do not happen at the same time scale, and depend on different environment conditions (Benech-Arnold et al., 2000). L. multiflorum seeds showed high primary dormancy, that was overcome very fast probably due to high summer temperatures, and then they germinated. The secondary dormancy of the seeds that did not germinate in autumn was not so high, when submitted to the required conditions for germination, during the test in the laboratory.

Dormancy of $L$. multiflorum seeds can have environmental or genetic causes, and can be influenced by a lot of unknown factors that change in space and time (Jensen and Pierpoint, 1960).

Most of the decrease in the number of seeds found in the bags after 108 days of burial was probably due to germination. L. multiflorum seeds are dormant until four months after physiological maturity, showing maximum germination just after the third month (Jensen and Pierpoint, 1961; Bazzigalupi, 1982), which coincides with the season of the first exhumation period. In this same period, it was also possible to observe the highest number of seedlings in a local pasture (Maia et al., 2008). However, predation and decay can also contributed to this result. The consequences of the predation patterns that are very variable in the population dynamic of plants are potentially strong (Crawley, 2000). In his studies, Hulme (1996) showed that relatively big seeds as Festuca pratensis, Lolium perenne and Trifolium pratense, that have similar size and shape to L. multiflorum, were the most predated seeds by small mammals after burial when 
compared to other species.

The results after 226 and 565 days of burial were significantly different, probably because of the higher field germination percentage in the first case and the higher non identified lost in the second. This higher field germination percentage can be a consequence of the fact that some bags were not at their initial position in the soil but close to the soil surface, probably due to the activity of some animal. The other periods did not show significant differences, being evident that the overcoming of primary dormancy by high summer temperatures and the small degree of secondary dormancy allow germination of most part of the seeds still in autumn.

Roberts (1988) recognizes three different physiological processes in seeds affected by temperature: i) temperature, along with moisture, determining the deterioration index in all seeds; ii) temperature affecting the degree of dormancy overcome, in dry seeds, and the patterns of modification in dormancy in moist seeds; iii) in non dormant seeds, temperature determines the germination.

When seeds of winter annual species such as L. multiflorum are in primary dormancy, just after dispersion, germination is restricted to small amplitudes of low temperatures (Baskin and Baskin, 2001; Probert, 2000). During the end of spring and beginning of summer, soil temperatures are normally higher than the favorable maximum temperature

Few seeds remained viable for one and a half year in the soil, with a germination rate of $67 \%$. McDonald et al. (1996) observed similar behavior to L. perenne, mentioning that the species have both transient and short-persistent soil seed bank (viable for 1 to 5 years). Most of the records for $L$. multiflorum, classify the seed bank as transient, although we can also find classifications as short-term persistent and even as long-term persistent (Thompson et al., 1997).

There are some evidences that soil and climate may influence seed longevity (Bekker et al., 1998b; Blaney and Kotanen, 2001; Cavieres and Arroyo, 2001). Fenner and Thompson (2005) concluded that seed persistence is chiefly a species trait but it can be modified by environmental conditions.

As there were few seeds still able to germinate when samples were exhumed and the dormancy rates were low, the study is in agreement with the one led by Thompson and Grime (1979) in England and D'Angela et al. (1988) in Argentina, which classified L. multiflorum as a specie with a transient soil seed bank, in pastures submitted to seasonal disturbances (drought or grazing), being part of the regenerative mechanisms where mortalities in the population of established plants are recovered annually during a particularly favourable station.

In this way, it is evident that in annual pastures the transitory seed banks have a main role in the regeneration of the species, along with the most persistent portion of seeds (Levassor, 1990). With this information, it is possible to say that the no tillage systems managed for natural re-sowing of the winter grass species that are observed in the region are very fragile and totally dependant on the previous seed production, as the dormancy period of the species does not take as long as it was thought and just few seeds remain in the soil throughout the year.

\section{CONCLUSIONS}

Part of the annual ryegrass seeds, dispersed in the end of the spring, keeps dormant during the summer, and those that survive germinate in the autumn, after dormancy overcome, probably due to the high summer temperatures and the required conditions for germination of the autumn.

The annual ryegrass secondary dormancy is very low and few seeds are viable in the soil throughout the year.

As few seeds of the species could germinate after more than one year of burial, the seed bank was classified, in this study, as transitory.

The soybean no tillage system with annual ryegrass, managed for natural resowing and grazed, is totally dependant on the annual seed production, as the seeds are not able to keep viable in the soil for long periods.

\section{REFERENCES}

BAKKER, J.P.; BERENDSE, F. Constraints in the restoration of ecological diversity in grassland and heathland communities. Trends in Ecology and Evolution, v.14, n.2, p.63-68, 1999.

BASKIN, C.C.; BASKIN, J.M. Seeds: ecology, biogeography, and evolution of dormancy and germination. 2 ed., San Diego: Academic Press, 2001. 666p.

BAZZIGALUPI, O. Efeito da época de colheita sobre o rendimento e a qualidade de sementes de azevém anual. Pelotas, 1982. 74f. Dissertação (Mestrado em Ciência e Tecnologia de Sementes) - Programa de Pós-Graduação em Ciências Agrárias, Universidade Federal de Pelotas, 1982.

BEKKER, R.M.; KNEVEL, I.C.; TALLOWIN, J.B.R.; TROOST, E.M.L.; BAKKER, J.P. Soil nutrient input effects on seed longevity: a burial experiment with fen-meadow species. Functional Ecology, v.12, n.4, p.673-682, 1998a. 
BEKKER, R.M.; OOMES, M.J.M.; BAKKER, J.P. The impact of groundwater level on soil seed bank survival. Seed Science Research, v.8, n.3, p.399-404, 1998b.

BEKKER, R.M.; SCHAMINEE, J.H.J.; BAKKER, J.P.; THOMPSON, K. Seed bank characteristics of Dutch plant communities. Acta Botanica Neerlandica, v.47, n.1, p.15$26,1998 \mathrm{c}$.

BENECH-ARNOLD,R.L.;SÁNCHEZA,R.A.;FORCELLA, F.; KRUKA, B.C.; GUERSAA, C.M. Environmental control of dormancy in weed seed banks in soil. Field Crops Research, v.67, n.2, p.105-122, 2000.

BLANEY, C.S.; KOTANEN, P.M. Effects of fungal pathogens on seeds of native and exotic plants: a test using congeneric pairs. The Journal of Applied Ecology, v. 38, p.1104-1013, 2001.

BRASIL. Ministério da Agricultura e Reforma Agrária. Regras para Análise de Sementes. [Rules for Seed Tests]. Brasília: SNAD/DNDV/CLAV, 1992. 365p.

BRYANT, J.A. Fisiologia da Semente. [Seed Physiology]. São Paulo: EPU, 1989. 86p. (Temas de Biologia, 31).

CAVIERES, L.A.; ARROYO, M.T.K. Persistent soil seed banks in Phacelia secunda (Hydrophyllaceae): experimental detection of variation along an altitudinal gradient in the Andes of central Chile (33 degrees S). The Journal of Ecology, v.89, p.31-39, 2001.

COOK, R. The biology of seeds in the soil. In: SOLBRIG, O.T. (Ed.). Demography and evolution in plant populations. Botanical Monographs, v.15, p.107-129, 1980.

CRAWLEY, M.J. Seed predators and plant population dynamics. In: FENNER, M. (Ed.). Seeds: the ecology of regeneration in plant communities, Wallingford: CABI, 2000. p.157-191.

D'ANGELA, E.; FACELLI, J.M.; JACOBO, E. The role of permanent soil seed bank in early stages of a post-agricultural succession in the Inland Pampa, Argentina. Vegetatio: Acta Geobotanica, v.74, p.39-45, 1998.

FENNER, M.; THOMPSON, K. The ecology of seeds. Cambridge: Cambridge University Press, 2005. 250p.

HARPER, J.L. Population biology of plants. London: Academic Press, 1977. p.33-111.

HULME, P.E. Herbivory, plant regeneration and species coexistence. The Journal of Ecology, v.84, p.609-615, 1996.

JENSEN, L.; PIERPOINT, M. Dormancy in common ryegrass. Newsletter Association of Seed Analysis, v.35, n.4, p.31-33, 1960.

JENSEN, L.; PIERPOINT, M. Survey of post harvest dormancy in Oregon ryegrass samples. Proc. Association of Seed Analysis, n.51, p.178-183, 1961.

LEVASSOR, C.; ORTEGA, M.; PECO, B. Seed bank dynamics of Mediterranean pastures subjected to mechanical disturbance. Journal of Vegetation Science, v.1, p.339-344, 1990.

LÓPEZ-MARIÑO, A.; LUIS-CALABUIG, E.; FILLAT, F.; BERMUDEZ, F.F. Floristic composition of established vegetation and the soil seed bank in pasture communities under different traditional management regimes. Agriculture Ecosystems and Environment, v.78, n.3, p.273-282, 2000.

MAIA, F.C.; MAIA, M.S.; BEKKER, R.M.; BERTON, R.P.; CAETANO, L.S. Lolium multiflorum seeds in the soil: I. Soil seed bank dynamics in a no tillage system. Revista Brasileira de Sementes, v.30, n.2, 2008.

MC DONALD, A.W.; BAKKER, J.P.; VEGELIN, K. Seed bank classification and its importance for the restoration of species-rich flood-meadows. Journal of Vegetation Science, v.7, p.157-164, 1996.

PETTIT, N.E.; FROEND, R.H. Availability of seed for recruitment of riparian vegetation: a comparison of a tropical and a temperate river ecosystem in Australia. Australian Journal of Botany, v.49, n.4, p.515-528, 2001.

PILLAR, V.P. Multivariate exploratory analysis and randomization testing with MULTIV. Coenoses, v.12, p.145-148, 1997.

PILLAR, V.P. MULTIV: aplicativo para análise multivariada e testes de hipóteses - versões para Macintosh e Windows. [MULTIV: software for multivariate analysis and hypothesis tests - versions for Macintosh and Windows]. Ecology Department of the Federal University of Rio Grande do Sul, Porto Alegre, 1994-2004.

PROBERT, R.J. The role of temperature in seed dormancy and germination. In: FENNER, M. (ed.). Seeds: the ecology of regeneration in plant communities. 2 ed., Wallingford: CABI, 2000. p.261-292.

ROBERTS, E.H. Temperature and seed germination. In: LONG, S.P.; WOODWARD, F.I. (Eds.). Plants and Temperature. Symposia of the Society of Experimental Biology, Company of Biologists, Cambridge, p.109-132, 1988.

STOCKLIN, J.; FISCHER, M. Plants with longer-lived seeds have lower local extinction rates in grassland remnants 19501985. Oecologia, v.120, n.4, p.539-543, 1999. 
SYMONIDES, E. Seed banks in old-field successional ecosystems. Polish Journal of Ecology, v.34, n.3, p.29, 1986.

THOMPSON, K.; GRIME, J.P. Seasonal variation in the seed banks of herbaceous species in ten contrasting habitats. Journal of Ecology, v.67, p.893-921, 1979.
THOMPSON, K.; BAKKER, J.P.; BEKKER, R.M. The soil seed banks of North West Europe: methodology, density and longevity. Cambridge: Cambridge University Press, 1997. 276p.

THOMPSON, K.; CERIANI, R.M.; BAKKER, J.P.; BEKKER, R.M. Are seed dormancy and persistence in soil related? Seed Science Research, v.13, p.97-100, 2003. 